\title{
OECD/DAC 양성평등네트워크 회의
}

OECD/DAC GENDERNET에서는 Task Team 회의 및 INCAF와의 공동워크숍을 개최하고, 그간의 활동 성과 및 향후 과제와 더불어 INCAF와의 공조강화 방안 등에 대해 논의한 바, 동 회의 개요 및 주요 논의 내용을 아래에 서술함.

\section{I. 회의 개요}

○ 회의명 : $\mathrm{OECD} / \mathrm{DAC}$ 젠더넷 회의

일시 : 2010년 10월 14일 15일

\section{II. 주요 내용}

\section{1. 변화된 개발환경에 따른 GENDERNET고유의 역할 및 기능}

O MDG정상회의 및 UNWOMEN 출범 등을 계기로 개발협력에서의 성평등 이슈의 중요성이 국제 적으로 재확인되었으나, $\mathrm{OECD} / \mathrm{DAC}$ 만이 가질 수 있는 구체적 역할과 기여방안에 대한 구체적 논의가 필요

O 개발효과성으로의 패러다임 전환 및 이에 따른 DAC mandate 개정 논의를 감안한 GENDERNET 의 향후 활동전략 수립이 필요

\section{2. 회원국들의 활동과 원조효과작업반활동의 연계가 필요}

GENDERNET의 HLF-4 기여방안에 대한 논의시, issue briefing, PD survey for gender module 과 같은 네트워크의 성과 등을 기초로 한 다양한 활동들을 원조효과 작업반 활동과 연계시키는 것 이 중요함 


\section{INCAF와의 상호협력 강화}

GENDERNET-INCAF 공동 워크숍에서 분쟁-취약국에 대한 지원의 효과성 제고를 위해서는 젠더 이슈에 대한 고려가 중요함을 재확인하고, 그간 양 네트워크의 업무성과를 바탕으로 상호협력을 강화해 나가기로 함.

\section{III. 평가}

○ 금번 회의기간 중 OECD Council 회의에 특별 참석한 Melanne Verveer 미국 Global women's issue 대사는 경제성장에 있어 여성의 교육 및 경제력 향상, 모자보건 개선의 중요성을 강조하 고 향후 미국정부는 동 이슈에 대한 지원을 대폭 확대해 나갈 계획임을 밝혔으며, UN에서도 UNWOMEN 출범과 더불어 모자보건 향상을 위한 400억불 규모의 이니셔티브 착수 등을 소개함.

O 이러한 일련의 최근 동향들을 통해 젠더와 개발에 대한 국제사회의 관심과 논의가 확대되고 있 음이 관찰된 바, G20, HLF-4 등 주요 개발관련 국제행사를 준비 중인 우리나라에서도 젠더이 슈에 대한 이해를 제고함과 아울러 주요 논의사항에 대한 한국의 입장을 정립해 나갈 필요가 있음.

O 특히, UNWOMEN의 설립을 계기로 향후 젠더이슈에 대한 국제적 논의가 활발히 전개될 것으로 전망되므로 한국도 global gender issue 관련 대내외 협력체제 구축 등을 통해 효율적 대응방 안을 모색해야 하며, 아울러 젠더 측면에서의 개발원조 실적 및 성과사례들을 체계적으로 정리 하고 홍보하여 동 이슈에 대한 한국의 기여를 가시화시켜 나갈 필요가 있을 것임. 